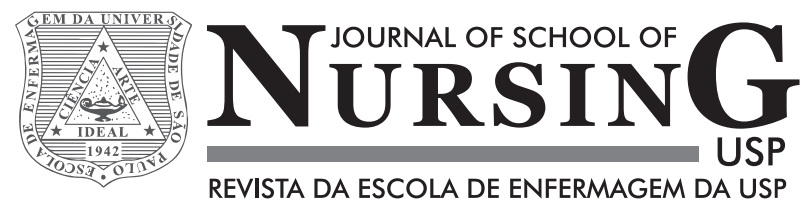

\title{
Handgrip strength and physical activity in frail elderly*
}

\author{
Força de preensão manual e atividade física em idosos fragilizados \\ Fuerza de agarre manual y actividad física en ancianos fragilizados
}

\author{
Maria Helena Lenardt ${ }^{1}$, Maria Angélica Binotto ${ }^{1}$, Nathalia Hammerschmidt Kolb Carneiro $^{1}$, Clovis Cechinel ${ }^{1}$, Susanne \\ Elero Betiolli', Tânia Maria Lourenço ${ }^{1}$
}

\section{How to cite this article:}

Lenardt MH, Binotto MA, Carneiro NHK, Cechinel C, Betiolli SE, Lourenço TM. Handgrip strength and physical activity in frail elderly. Rev Esc Enferm USP. 2016;50(1):86-92. DOI: http://dx.doi.org/10.1590/S0080-623420160000100012

\begin{abstract}
* Extracted from the research project "Efeitos da fragilidade e qualidade de vida relacionada à saúde de idosos da comunidade", Universidade Federal de Curitiba, 2010-2013.

${ }^{1}$ Universidade Federal do Paraná, Programa de Pós-Graduação em Enfermagem, Curitiba, PR, Brazil.
\end{abstract}

\begin{abstract}
Objective: To investigate the association between handgrip strength (HS) and physical activity in physical frailty elderly. Method: Cross-sectional quantitative study with a sample of 203 elderly calculated based on the population estimated proportion. Tests were applied to detect cognitive impairment and assessment of physical frailty. Descriptive statistics and multivariate analysis by binary logistic regression were used, and also Student's t-test and Fisher's exact test. Results: A total of 99 (64.3\%) elderly showed decreased handgrip strength and 90 (58.4\%) elderly presented decrease in physical activity levels. There was a statistically significant difference between these two components $(\mathrm{p}=0.019)$, in which elderly who have decreased HS have lower levels of physical activity. For low levels of physical activity and decreased HS, there was no evidence of significant difference in the probability of the classification as frail elderly $(p<0.001)$. Conclusion: The components handgrip strength and physical activity are associated with the frail elderly. The joint presence of low levels of physical activity and decreased handgrip strength leads to a significantly higher probability of the elderly to be categorized as frailty.
\end{abstract}

\section{DESCRIPTORS}

Elderly; Frail Elderly; Motor Activity; Muscle Strength Dynamometer; Hand Strength; Geriatric Nursing.

\author{
Corresponding author: \\ Maria Angélica Binotto \\ Programa de Pós-Graduação \\ em Enfermagem - UFPR \\ Av. Pref. Lothario Meissner, 632 \\ $3^{\circ}$ andar - Jardim Botânico \\ CEP 80210-170 - Curitiba, PR, Brasil \\ manbinotto@yahoo.com.br
}




\section{INTRODUCTION}

The aging concerning researches are still incipient, therefore, their results are often being studied, particularly when dealing with components that are involved in the physical aging process. The process would not be problematic if there were not, usually, association between physical frailty and risk of functional decline in the elderly. Thus, researches on physical frailty are essential for gerontology, since they subsidize geriatric care for a practice rooted in active aging to implement preventive interventions before disabling conditions of the elderly ${ }^{(1)}$.

Physical frailty is defined by a group of American researchers as "a medical syndrome with multiple causes, characterized by decreased strength, endurance and reduction in physiological functions that increase the individual's vulnerability to developing and increasing dependency and/or death"(2).

Frailty syndrome in the elderly can be verified by five measurable biological characteristics, which composes the phenotype of frailty: reduced walking speed, reduced handgrip strength, loss of unintentional weight, decreased level of physical activity and self-reported fatigue/exhaustion ${ }^{(3)}$. Elderly who have three or more of these characteristics can be considered frail, one who have one or two characteristics is in a state prior to the frailty (pre-frail) the ones who do not exhibit any of the characteristics mentioned are considered non-frail elderly ${ }^{(3)}$. In this study, the term frailty condition will be used to refer to the pre-frail and frail groups.

According to the American Medical Association, it is estimated that 10 to $25 \%$ of people over 65 years are frail, and this prevalence increases proportionally with age and reaches more than $40 \%$ in those over 80 years $^{(3)}$. A study conducted for four years in the USA ${ }^{(4)}$, involving 5,317 elderly aged over 65 years, found a prevalence of $46.6 \%$ of pre-frail elderly and $6.9 \%$ of frail. Still, in the frail elderly, the risk of falling, decreased mobility, dependence for activities of daily living, institutionalization and death, increased from 1.2 to 2.5 times $^{(4)}$.

The loss of bone and muscle mass and consequent decrease in quality and musculoskeletal performance can lead to the frailty syndrome in old age, and disability and dependency, frequent falls and hospitalizations ${ }^{(5)}$.

Sarcopenia, according to European Working Group on Sarcopenia in Older People (EWGSOP), is one of the geriatric syndromes and is characterized as a progressive and generalized decrease in skeletal muscle mass at risk for adverse outcomes such as functional disability, poorer quality of life and death ${ }^{(6)}$.

This process is considered slow, progressive and apparently inevitable, even for those healthy and physically active subjects and its consequences directly affect the functionality and quality of life of many elderly, with serious repercussions on the social, economic and health aspects.

Decreased muscle strength, assessed by handgrip strength, as a component of physical frailty ${ }^{(4)}$ becomes an important tool for health professionals and researchers. Handgrip strength is used as a predictor of the overall state of strength and it is associated with mortality and disability ${ }^{(7-8)}$.
A study conducted with data from Women's Health and Aging Study ${ }^{(9)}$ showed that the risk of disability in instrumental activities of daily living and becoming frail were 1.35 and 1.47 times higher, respectively, for each unit of 0.50 $\mathrm{kgf}$ decreasing handgrip. In addition, handgrip strength was significantly associated with the other components of the frailty syndrome ${ }^{(10)}$, including the level of physical activity.

Scientific literature has pointed to the benefits that physical activity practice provides to the elderly, being important in disease prevention, maintenance of independence and improving quality of life ${ }^{(11-12)}$. Frailty is one of the most important reasons to prescribe physical exercise, as this is considered a protective factor against various components of the condition being studied ${ }^{(5)}$.

This study is justified by the understanding of how one of the physical frailty markers behave in front of a factor considered as protection and treatment. This understanding is more clearly expressed on the elements that composes the management of physical frailty and consequently subsidizes the adequacy of care, in order to treat and prevent physical frailty in the elderly.

In view of the facts raised, the objective of the study was to investigate the association between handgrip strength and physical activity in older adults with physical frailty condition.

\section{METHOD}

The materials and methods in this study are similar to the ones from a greater project entitled Effects of fragility and health-related quality of life in community elderly.

This is a quantitative cross-sectional study, carried out in a Basic Health Unit (BHU), from the city of Curitiba (PR). The target population consisted of elderly awaiting consultation at a $\mathrm{BHU}$, selected using the following inclusion criteria: a) aged 60 years or older; b) being registered in the BHU where the study was conducted; c) providing cognitive ability, through cutoffs points ${ }^{(13)}$ in the MiniMental State Examination (MMSE) ${ }^{(14)}$. The Exclusion criteria were: having diseases, problems and physical and mental symptoms that, for whatever reason, prevented the questionnaires and the tests to be applied.

The sample size was determined based on the estimated population proportion. A 95\% confidence interval was used $(\alpha=0.05)$ and sampling error fixed at five percentage points. To the sample size $10 \%$ was added due to the possibilities of losses and refusals, resulting in a sampling size consisting of 203 elderly. The sample was recruited by convenience; individuals were invited to participate in the study in order of arrival to the $\mathrm{BHU}$ reception. Data collection occurred from January to April 2013. Initially, we applied the MMSE ${ }^{(14)}$ for cognitive screening and the following cutoff points used were: 13 points to low education, 18 points for medium education and 26 points for higher education ${ }^{(13)}$. Elderly who presented cognitive scores below the cutoff points mentioned were excluded.

Although there were different definitions and ways of assessing the frailty syndrome, for this study, we adopted the definition and the assessment criteria proposed by Fried ${ }^{(3)}$. 
The phenotype of physical frailty was measured through the assessment of the five markers: low level of physical activity, self-reported fatigue/exhaustion, unintentional weight loss, decreased handgrip strength and reduced walking speed ${ }^{(3)}$. In order to make effective the specificity of Brazilian elderly, changes were made to the assessment to identify the level of physical activity and fatigue/exhaustion.

For the physical activity component, we applied the Questionário de Nivel de Atividade Física para Idoso-CuritibAtiva ${ }^{(15)}$. The questionnaire has 20 questions regarding the frequency and time of the physical activity performed in the past week and the score is converted into the following classification: inactive (0-32); minimally active (33-82); moderately active (83-108); active (109-133); very active ( $\geq 134)$, according to the recommendation of the Compendium of Physical Activities Tracking Guide ${ }^{(15)}$. The inactive or minimally active were considered weak frailty markers.

Fatigue/exhaustion was measured by self-report as positive or negative response to the question from the Depression Scale of Epidemiological Studies Center (CES-D) ${ }^{(16)}$ : Do you feel full of energy? Also, the energy level was measured through a visual scale using a numbered ruler, zero being the value corresponding to minimum energy and ten to the maximum. The negative response of the subject to the CES-D was the marker of frailty when the value indicated on the scale are equal to or less than three ${ }^{(17)}$.

Unintentional weight loss was measured by self-report in two questions: Did you lose weight in the last twelve months? How many Kilograms? Participants were classified according to the cutoff points for body mass index (BMI) (18). It was considered frailty marker self-reports of weight loss $\geq 4,5$ kilograms $(\mathrm{kg})$ in the last twelve months ${ }^{(4)}$ or presented BMI below percentile $22^{(18)}$.

To assess walking speed, the participant was instructed to walk six meters, in the usual way, on a flat surface, signaled by two brands ${ }^{(19)}$. The time was recorded in seconds to perform the four intermediate meters. After adjusting for gender ${ }^{(4)}$, the values that were in the lowest quartile were considered frailty markers.

The handgrip strength (HS) was measured with a dynamometer $\left(\operatorname{Jamar}^{\circledR}\right)$ in the dominant hand. The el- derly remained sit with his feet touching the ground and the upper limb in test was positioned: shoulder adduction, elbow joint flexed to $90^{\circ}$ and forearm in neutral position. The subject performed three handgrip strength interspersed by 1 minute and the highest measure observed was considered ${ }^{(19)}$. After adjusting for gender ${ }^{(4)}$, the values that were in the lowest quartile were considered frailty markers.

The variables considered were age, gender, physical frailty, physical activity level, handgrip strength, walking speed, fatigue/exhaustion, loss of unintentional weight and BMI.

Data were organized in the computer software Excel 2007, being double-checked. Then, the same database was verified by a third person, in order to reduce errors. Descriptive statistics, multivariate binary logistic regression analysis, with calculation of the odds ratio (OR), Student's $t$ test and Fisher's exact test were used. $P$ values $<0.05$ were considered statistically significant. Statistical analyzes were performed using the Statistical Package for Social Sciences (SPSS) version 21.

The study was approved by the Research Ethics Committee in Human Beings of the Health Sciences Sector, being approved under registration CEP/SD: 913.038.10.04 CAAE: 0023.0.091.000-10. The ethical principles of voluntary and informed participation of each subject were consented, according to Resolution N ${ }^{\circ}$. 196, effective at the project approval period.

\section{RESULTS}

The study included 203 elderly men and women $(60.6 \%$ women and $39.4 \%$ men) with a mean age of $70.8 \pm 7.4$ years, and most were within the age group of 65-69.9 years (25.6\%). A total of 39 participants were classified (19.2\%) as frail elderly, $115(56.7 \%)$ pre-frail and 49 (24.1\%) non-frail.

The frailty condition (frail and pre-frail) was present in 154 (75.9\%) participants. From these, handgrip strength was decreased in 99 (64.3\%) elderly, 62 (40.3\%) pre-frail and 37 (24\%) frail. For the physical activity component (PA), 90 (58.4\%) had low levels of physical activity, of these, 57 (37\%) were pre-frail and $33(21.4 \%)$ frail (Table 1).

Table 1 - Distribution of handgrip strength and physical activity components for pre-frail and frail groups - Curitiba, PR, Brazil, 2013.

\begin{tabular}{lcccccc}
\hline & \multicolumn{3}{c}{ Decreased handgrip strength } & \multicolumn{3}{c}{ Low levels of physical activity } \\
\cline { 2 - 7 } Frailty Condition & $\begin{array}{c}\text { Yes } \\
\mathbf{n}(\%)\end{array}$ & $\begin{array}{c}\text { No } \\
\mathbf{n}(\%)\end{array}$ & $\begin{array}{c}\text { Total } \\
\mathbf{n}(\%)\end{array}$ & $\begin{array}{c}\text { Yes } \\
\mathbf{n}(\%)\end{array}$ & $\begin{array}{c}\text { No } \\
\mathbf{n}(\%)\end{array}$ & $\begin{array}{c}\text { Total } \\
\mathbf{n}(\%)\end{array}$ \\
\hline Pre-frail & $62(40.3)$ & $53(34.4)$ & $115(74.6)$ & $57(37.0)$ & $58(37.7)$ & $115(74.6)$ \\
Frail & $37(24.0)$ & $2(1.3)$ & $39(25.3)$ & $33(21.4)$ & $6(3.8)$ & $39(25.3)$ \\
Total & $99(64.3)$ & $55(35.8)$ & $154(100.0)$ & $90(58.4)$ & $64(41.5)$ & $154(100.0)$ \\
\hline
\end{tabular}

The mean HS presented by the pre-frail and frail elderly was $28.4 \pm 9,8 \mathrm{kgf}$ and $22.5 \pm 6,1 \mathrm{kgf}$ respectively. These mean values were statistically significant between the pre-frail and frail groups $(\mathrm{p}=0.000)$.
The elderly who showed decreased HS (Table 2), 49 (31.9\%) were categorized as minimally active (18.9\%) and inactive (13.0\%). Thus, elderly who showed a decrease of HS were categorized with low levels of physical activity. 
Table 2 - Frequency distribution for handgrip strength decreased according to different levels of physical activity in pre-frail and frail elderly groups - Curitiba, PR, Brazil, 2013.

\begin{tabular}{lccc}
\hline & \multicolumn{3}{c}{ Decreased handgrip strength } \\
\cline { 2 - 4 } Categorization of physical activity & Yes & $\begin{array}{c}\text { No } \\
\mathbf{n}(\%)\end{array}$ & $\begin{array}{c}\text { Total } \\
\mathbf{n}(\%)\end{array}$ \\
\hline Very active & $\mathbf{n}(\%)$ & $8(5.2)$ & $36(23.4)$ \\
Active & $28(18.2)$ & $5(3.2)$ & $14(9.1)$ \\
Moderately active & $9(5.9)$ & $4(2.6)$ & $17(11.0)$ \\
Minimally active & $13(8.4)$ & $25(16.2)$ & $54(35.1)$ \\
Inactive & $29(18.9)$ & $13(8.4)$ & $33(21.4)$ \\
\hline Total & $20(13.0)$ & $55(35.8)$ & $154(100.0)$ \\
\hline
\end{tabular}

As for the components of physical frailty investigated, there was a statistically significant difference between the level of physical activity and handgrip strength $(p=0.019)$, ie, elderly with decreased HS have lower levels of physical activity (Table 3).

Table 3 - Logistic regression values for handgrip strength and physical activity variables in the elderly - Curitiba, PR, Brazil, 2013.

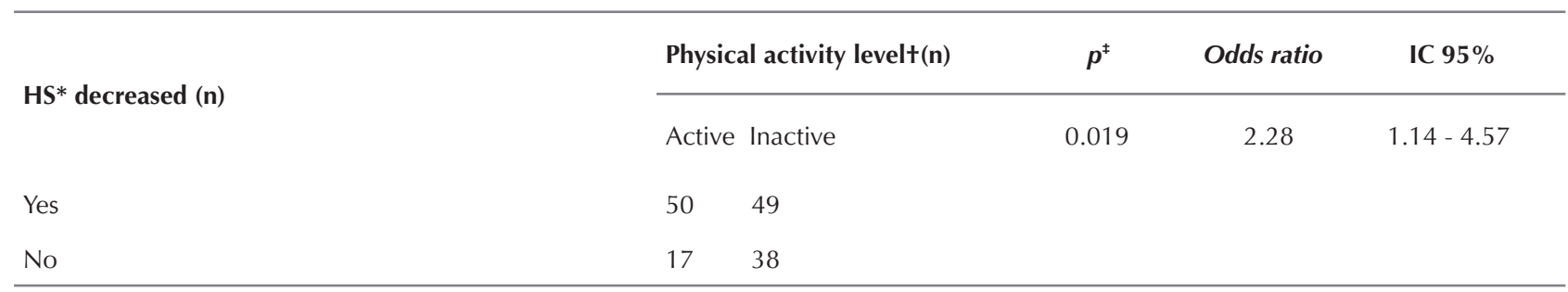

*Handgrip strength

†For statistical analysis, we considered active (very active + active+ moderately active) and inactive (minimally active + inactive).

‡ Binary logistic regression.

It is observed in Table 4 the distribution of handgrip strength and physical activity as components for the frailty condition in the investigated elderly. For the pre-frail elderly, 20 (17.4\%) participants had low levels of physical activity and HS decreased, while the participants in frail group, 31 (79.5\%) had the same condition. Thus, decreased HS and low levels of physical activity are more present in the group of frail elderly, when compared to the pre-frail.

Table 4 - Distribution of handgrip strength and physical activity as components of the frailty condition - Curitiba, PR, Brazil, 2013.

\begin{tabular}{|c|c|c|c|c|}
\hline \multirow{2}{*}{$\begin{array}{l}\text { Frailty } \\
\text { condition }\end{array}$} & \multirow[b]{2}{*}{ Decreased HS* } & \multicolumn{3}{|c|}{ Low level of physical activity } \\
\hline & & $\begin{array}{c}\text { Yes } \\
\text { n (\%) }\end{array}$ & $\begin{array}{c}\text { No } \\
\text { n (\%) }\end{array}$ & $\begin{array}{l}\text { Total } \\
\text { n (\%) }\end{array}$ \\
\hline \multirow{3}{*}{ Pre-Frail } & Yes & $20(17.4)$ & $42(36.5)$ & $62(54.0)$ \\
\hline & No & $37(32.2)$ & $16(14.0)$ & $53(46.0)$ \\
\hline & Total & $57(49.6)$ & $58(50.5)$ & $115(100.0)$ \\
\hline \multirow{3}{*}{ Frail } & Yes & $31(79.5)$ & $6(15.4)$ & $37(94.9)$ \\
\hline & No & $2(5.1)$ & - & $2(5.1)$ \\
\hline & Total & $33(84.6)$ & $6(15.4)$ & $39(100.0)$ \\
\hline
\end{tabular}

*HS = Handgrip strength.

In Table 5, we can observe the probability of the elderly frailty classification from different combinations of presence and absence of the HS and PA components. The result indicates that there is no evidence that the probability of an elderly being classified as frail is greatly increased by the presence of only decreased HS ( $p=0.323$ ). Also, there is not a significant increase in the probability of an elderly of only being classified as frail in the presence of PA ( $p=1.000)$. For low levels of physical activity and decreased HS, there was evidence of significant difference in the probability of frail score $(p<0.001)$. These results indicate that the combined presence of low levels of physical activity and decreased HS leads to a significantly more likely to be categorized as frail elderly. 
Table 5 - Probability for the classification of elderly to be frail from different combinations of presence and absence of handgrip strength and physical activity components - Curitiba, PR, Brazil, 2013.

\begin{tabular}{lcccccc}
\hline & & \multicolumn{2}{c}{ Frailty Condition } & & Total \\
\cline { 3 - 4 } PA $^{*}$ & $\mathbf{D H S}^{+}$ & $\begin{array}{c}\text { Pre-Frail } \\
\mathbf{n}(\%)\end{array}$ & $\begin{array}{c}\text { Frail } \\
\mathbf{n}(\%)\end{array}$ & $\begin{array}{c}\text { Probability to be } \\
\text { Frail (95\%CI) }\end{array}$ & P-value $^{\ddagger}$ \\
\hline \multirow{2}{*}{ No } & No & $16(100.0)$ & $0(0.0)$ & 16 & 0 & $\cdots$ \\
& Yes & $42(87.5)$ & $6(12.5)$ & 48 & $12.5(3.1-21.9)$ & 0.323 \\
\multirow{2}{*}{ Yes } & No & $37(94.9)$ & $2(5.1)$ & 39 & $5.1(0-12.1)$ & 1.000 \\
& Yes & $20(39.2)$ & $31(60.8)$ & 51 & $60.8(47.4-74.2)$ & $<0.001$ \\
\hline
\end{tabular}

*PA = Low level of physical activity.

$\dagger$ DHS = Decreases handgrip strength.

$\ddagger$ Fisher exact test.

\section{DISCUSSION}

The results of the physical frailty present similar behavior to findings in other national studies involving the elderly community. A study of seven Brazilian cities with a sample of 3,478 elderly found that $51.9 \%$ of the elderly were considered pre-frail, $39.1 \%$ were non frail and $9 \%$ frail $^{(20)}$.

The highest prevalence found in different studies are for the pre-frail group. Thus, initial detection of the pre-frail, according to the researchers of this area ${ }^{(3)}$, is essential for making effective strategies and opportunities for intervention, as these elderly are at risk of functional decline. In addition, elderly in pre-frail condition appear to respond better to intervention measures that can contribute to the prevention of the consequences and the aggravation of frailty ${ }^{(2-4)}$.

The handgrip strength and physical activity are markers for the frailty condition ${ }^{(3)}$. Data from the Health, Welfare and Aging study (SABE) involving 1,413 elderly living in the urban area of São Paulo found that 50.9\% and $40.1 \%$ elderly had muscle weakness and low levels of physical activity, respectively ${ }^{(21)}$. This result is most frequently found in elderly with decreased HS compared to those with low physical activity, which is similar to that found in this study. However, the frequency distribution of the frailty components differ, even among national studies, with the same form of assessment. This outcome may be associated with differences in population characteristics.

The mean values of HS are significantly lower for the frail elderly, when compared to groups of pre-frail elderly. This result can be explained by pathophysiological character of the frailty syndrome, in which frail elderly patients tend to have less muscle strength.

A population-based study, for the project Frailty in Brazilian Elderly (FIBER), assessed 689 elderly aged over 65 years and found mean handgrip strength $\left(\mathrm{Jamar}^{\circledR}\right.$ dynamometer) of $26.0 \mathrm{kgf}^{(22)}$. Intermediate result when compared to the mean values of the frail elderly group $(22.5 \pm 6.1$ $\mathrm{kgf})$ and pre-frail $(28.4 \pm 9.8 \mathrm{kgf})$ found in this study. The reduction in handgrip strength has been explored as an initial manifestation of frailty and may be present even before the emergence of other functional disabilities ${ }^{(23)}$.

Regarding physical activity, the health benefits in the aging process are consensual among gerontology experts, results of scientific findings and documents evidence the importance of encouraging physical activity in health actions ${ }^{(24-25)}$. This topic has been discussed in different areas, in meetings, forums, conferences, by different professionals of gerontology and geriatrics from different countries.

However, the human aging process leads to a decrease in physical activity and this is also confirmed in elderly. In a longitudinal study of 519 elderly residents in the metropolitan community of Chicago, United States, mean age $81.6 \pm 6.8$ years and followed for six years, showed that the rate of decline of total daily physical activity was lower in older participants and there is a more rapid decline with increasing age ${ }^{(26)}$.

A study with a random sample of community-dwelling elderly aged 65 and over, members of a population study on frailty, found that sedentary elderly or low weekly caloric expenditure, and the older elderly differed from active elderly and younger in fatigue, handgrip strength and walking speed ${ }^{(22)}$.

The SABE study ${ }^{(21)}$ concluded that physical activity, screening and control of depression, diseases that affect the central nervous system and chronic disease should be the focus of strategies to prevent, slow or even cure the frailty syndrome. Another study ${ }^{(27)}$ pointed out that in sedentary elderly, the chances of developing frailty increased significantly compared to the group of elderly practitioners of physical exercises. Still, the physical activity practice is associated with delay and progression of frailty condition.

The association between physical activity and handgrip strength found in this study is similar to a British study ${ }^{(28)}$, in which the authors stated that the variable physical inactivity in the elderly was significantly associated with low handgrip strength. Thus, physical inactivity is an important contributory factor for sarcopenia related to aging. Elderly men and women with lower levels of physical activity also have less muscle mass and consequently higher prevalence of physical disability ${ }^{(29)}$.

A study ${ }^{(21)}$ pointed out that, for both genders, ages, education, sedentary lifestyle and positive screen for depression were associated in a similar way with a frailty component. In addition, decreased handgrip strength, walking speed and energy expenditure may indicate an early sign of frailty.

\section{CONCLUSION}

It is inferred that there was a statistically significant association between frailty components in handgrip strength 
and physical activity. The joint presence of low levels of physical activity and decreased handgrip strength leads to a significantly higher probability of the elderly to be categorized as frail.

The study showed some limitations in raising discussions due to its cross-sectional design, which does not show the causes and consequences of the association between the variables of interest.
It is understood that the study presents relevant subsidies for geriatric care, by allowing the inference: regular physical activity is a primary preventive strategy to maintain and improve muscle strength levels, with the purpose of providing direct and indirect benefits for the prevention of injuries resulting from physical frailty in elderly. Thus, interventions that encourage a more active lifestyle involving this public become increasingly necessary.

\section{RESUMO}

Objetivo: Investigar a associação entre força de preensão manual e atividade física em idosos na condição de fragilidade física. Método: Estudo quantitativo transversal realizado com amostra de 203 idosos, calculada com base na estimativa da proporção populacional. Foram aplicados testes para rastreio da alteração cognitiva e avaliação da fragilidade física. Foram empregados: estatística descritiva e análise multivariada por regressão logística binária, teste t de Student e teste exato de Fisher. Resultados: 99 (64,3\%) idosos apresentaram força de preensão diminuída e $90(58,4 \%)$ diminuição do nível de atividade física. Houve diferença estatisticamente significativa entre essas duas componentes $(\mathrm{p}=0,019)$, na qual idosos que apresentam FPM diminuída possuem menores níveis de atividade física. Para os baixos níveis de atividade física e diminuída FPM houve evidência de diferença significativa em relação à probabilidade de classificação do idoso como frágil $(p<0,001)$. Conclusão: As componentes força de preensão manual e atividade física estão associadas em idosos na condição de fragilidade. A presença conjunta de baixos níveis de atividade física e diminuída força de preensão manual leva a uma probabilidade significativamente maior de o idoso ser categorizado como frágil.

\section{DESCRITORES}

Idoso; Idoso Fragilizado; Atividade Motora; Dinamômetro de Força Muscular; Força da Mão; Enfermagem Geriátrica.

\section{RESUMEN}

Objetivo: Investigar la asociación entre fuerza de agarre manual y actividad física en ancianos bajo la condición de fragilidad física. Método: Estudio cuantitativo transversal llevado a cabo con muestra de 203 ancianos, calculada en base a la estimación de la proporción poblacional. Fueron aplicadas pruebas para rastreo de la alteración cognitiva y evaluación de la fragilidad física. Se emplearon: estadística descriptiva y análisis multivariado por regresión logística binaria, test t de Student y prueba exacta de Fisher. Resultados: 99 (64,3\%) ancianos presentaron fuerza de agarre disminuida y 90 (58,4\%) diminución del nivel de actividad física. Hubo diferencia estadísticamente significativa entre ambos componentes $(\mathrm{p}=0,019)$, en la que los ancianos que presentan FAM reducido tienen menores niveles de actividad física. Para los bajos niveles de actividad física y reducida FAM hubo evidencia de diferencia significativa con relación a la probabilidad de clasificación del anciano como frágil $(p<0,001)$. Conclusión: Los componentes fuerza de agarre manual y actividad física están asociados en ancianos bajo la condición de fragilidad. La presencia conjunta de bajos niveles de actividad física y reducida fuerza de agarre manual lleva a una probabilidad significativamente mayor de que el anciano sea categorizado como frágil.

\section{DESCRIPTORES}

Anciano; Anciano Frágil; Actividad Motora; Dinamómetro de Fuerza Muscular; Fuerza de la Mano; Enfermería Geriátrica.

\section{REFERENCES}

1. Cesari M, Landi F, Vellas B, Bernabei R, Marzetti E. Sarcopenia and physical frailty: two sides of the same coin. Aging Neurosci [Internet]. 2014 [cited 2015 July 05]; 6:192. Available from: http://www.ncbi.nlm.nih.gov/pmc/articles/PMC4112807

2. Morley JE, Vellas B, Kan AV, Anker SD, Bauer JM, Bernabei R, et al. Frailty consensus: a call to action. J Am Med Dir Assoc [Internet]. 2013 [cited 2014 Jan 20];14(6):392-7. Available from: http://www.ncbi.nlm.nih.gov/pubmed/23764209.

3. Fried L, Ferrucci L, Darer J, Williamson JD, Anderson G. Untangling the concepts of disability, frailty and comorbidity: implications for improved targeting and care. J Gerontol A Biol Sci Med Sci [Internet]. 2004 [cited 2014 Feb 12];59(3):255-63. Available from: http:// biomedgerontology.oxfordjournals.org/content/59/3/M255.long

4. Fried LP, Tangen CM, Walston J, Newman AB, Hirsch C, Gottdiener J, et al. Frailty in older adults: evidence for a phenotype. J Gerontol A Biol Sci Med Sci. 2001;56(3):146-54.

5. Landi F, Abbatecola AM, Provinciali M, Corsonello A, Bustacchini S, Manigrasso L, et al. Moving against frailty: does physical activity matter? Biogerontology. 2010;11(5):537-45.

6. Cruz-Jentoft AJ, Baeyens JP, Bauer JM, Boirie Y, Cederholm T, Landi F, et al. Sarcopenia: European consensus on definition and diagnosis: report of the European Working Group on Sarcopenia in Older People. Age Ageing [Internet]. 2010 [cited 2014 Nov 22];39(4):412-23. Available from: http://www.ncbi.nlm.nih.gov/pmc/articles/PMC2886201/

7. Bohannon RW. Hand-grip dynamometry predicts future outcomes in aging adults. J Geriatr Phys Ther. 2008;31(1):3-10.

8. Gale CR, Martyn CN, Cooper C, Sayer AA. Grip strength, body composition and mortality. Int J Epidemiol [Internet]. 2007 [cited 2015 Apr 02];36(1):228-35. Available from: http://ije.oxfordjournals.org/content/36/1/228.long

9. Xue Q, Walston JD, Fried LP, Beamer BA. Prediction of risk of falling, physical disability and frailty by rate of decline in grip strength: the women's health and aging study. Arch Intern Med [Internet]. 2011 [cited 2014 May 15];171(12):1119-21. Available from: http://archinte. jamanetwork.com/article.aspx?articleid=487086 
10. Syddall H, Cooper C, Martin F, Briggs R, Sayer AA. Is grip strength a useful single marker of frailty? Age Ageing [Internet]. 2003 [cited 2014 June 25];32(6):650-6. Available from: http://ageing.oxfordjournals.org/content/32/6/650.long

11. Sun F, Norman IJ, While AE. Physical activity in older people: a systematic review. BMC Public Health [Internet]. 2013 [cited 2014 June 25];13:449. Available from: http://www.ncbi.nlm.nih.gov/pmc/articles/PMC3651278/

12. Bellavia A, Bottai M, Wolk A, Orsini N. Physical activity and mortality in a prospective cohort of middle-aged and elderly men: a time perspective. Int J Behav Nutr Phys Act [Internet]. 2013 [cited 2014 Apr 12];10:94. Available from: http://www.ncbi.nlm.nih.gov/pmc/ articles/PMC3750581/

13. Bertolucci PH, Brucki SM, Campacci SR, Juliano Y. O Mini-Exame do Estado Mental em uma população geral: impacto da escolaridade. Arq Neuropsiquiatr [Internet]. 1994 [citado 2014 jun. 05];52(1):1-7. Disponível em: http://www.scielo.br/pdf/anp/v52n1/01.pdf

14. Folstein MF, Folstein SE, McHugh PR. "Mini-mental state": a practical method for grading the cognitive state of patients for the clinician. J Psychiatr Res. 1975;12(3):189-98.

15. Rauchbach R, Wendling NM. Evolução da construção de um instrumento de avaliação do nível de atividade física para idosos Curitibativa. FIEP Bull [Internet]. 2009 [citado 2014 jun. 05];79:543-47. Disponível em: http://www.fiepbulletin.net/index.php/fiepbulletin/article/ view/3405

16. Almeida OP, Almeida SA. Confiabilidade da versão brasileira da Escala de Depressão em Geriatria (GDS) versão reduzida. Arq Neuropsiquiatr [Internet]. 1999 [citado 2014 jan. 22];57(2B):421-26. Disponível em: http://www.scielo.br/pdf/anp/v57n2B/1446.pdf

17. Retornaz F, Monette J, Batist G, Monette M, Sourial N, Small D, et al. Usefulness of frailty markers in the assessment of the health and functional status of older cancer patients referred for chemotherapy: a pilot study. J Gerontol A Biol Sci Med Sci. 2008;63(5):518-22.

18. Brasil. Ministério da Saúde; Secretaria de Atenção à Saúde, Departamento de Atenção Básica. Protocolos do Sistema de Vigilância Alimentar e Nutricional - SISVAN na assistência à saúde [Internet]. Brasília; 2008 [citado 2015 jul. 07]. Disponível em: http://189.28.128.100/ nutricao/docs/geral/protocolo_sisvan.pdf

19. Geraldes AA, Oliveira ARM, Albuquerque RB, Carvalho JM, Farinatti PTV. A força de preensão manual é boa preditora do desempenho funcional de idosos frágeis: um estudo correlacional múltiplo. Rev Bras Med Esporte [Internet]. 2008 [citado 2015 jul. 06];14(1):12-6. Disponível em: http://www.scielo.br/pdf/rbme/v14n1/a02v14n1.pdf

20. Neri AL, Yassuda MS, Araújo LF, Eulálio MC, Cabral BE, Siqueira MEC, et al. Metodologia e perfil sociodemográfico, cognitivo e de fragilidade de idosos comunitários de sete cidades brasileiras: Estudo FIBRA. Cad Saúde Pública [Internet]. 2013 [citado 2014 dez. 13];29(4):778-92. Disponível em: http://www.scielo.br/pdf/csp/v29n4/15.pdf

21. Alexandre TS, Corona LP, Nunes DP, Santos JLF, Duarte YAO, Lebrão ML. Similarities among factors associated with components of frailty in elderly: SABE Study. J Aging Health. 2014;26(3):441-57.

22. Bez JPO, Neri AL. Velocidade da marcha, força de preensão e saúde percebida em idosos: dados da Rede FIBRA Campinas, São Paulo, Brasil. Ciênc Saúde Coletiva [Internet]. 2014 [citado 2014 dez. 10];19(8):3343-53. Available from: http://www.scielo.br/pdf/csc/ v19n8/1413-8123-csc-19-08-03343.pdf

23. Xue QL, Bandeen-Roche K, Varadhan R, Zhou J, Fried LP. Initial manifestations of frailty criteria and the development of frailty phenotype in the Women's Health and Aging Study II. J Gerontol A Biol Sci Med Sci. 2008;63(9):984-90.

24. Cederholm T, Cruz-Jentoft AJ, Maggi S. Sarcopenia and fragility fractures. Eur J Phys Rehabil Med. 2013;49(1):111-7.

25. New Zealand. Ministry of Health. Guidelines on Physical Activity for Older People (aged 65 years and over) [Internet]. Wellington; 2013 [cited 2015 Jan 28]. Available from: http://www.health.govt.nz/publication/guidelines-physical-activity-older-people-aged-65-years-andover

26. Buchman AS, Wilson RS, Yu L, James BD, Boyle PA, Bennett DA. Total daily activity declines more rapidly with increasing age in older adults. Arch Gerontol Geriatr [Internet]. 2014 [cited 2015 Jan 16];58(1):74-79. Available from: http://www.ncbi.nlm.nih.gov/pmc/articles/ PMC3889486/

27. Peterson MJ, Giuliani C, Morey MC, Pieper CF, Evenson KR, Mercer V, et al. Physical activity as a preventative factor for frailty: the health, aging, and body composition study. J Gerontol A Biol Sci Med Sci [Internet]. 2009 [cited 2014 May 20];64A(1):61-8. Available from: http:// www.ncbi.nlm.nih.gov/pmc/articles/PMC2913907/

28. Kuh D, Bassey E, Butterworth S, Hardy R, Wadsworth M. Grip strength, postural control, and functional leg power in a representative cohort of British men and women: associations with physical activity, health status, and socioeconomic conditions. J Gerontol A Biol Sci Med Sci. 2005;60(2):224-31.

29. Evans WJ. Effects of exercise on senescent muscle. Clin Orthop Relat Res. 2002;(403 Suppl):S211-20. 